\title{
ÉLELMISZEREKKEL KAPCSOLATOS KOCKÁZATOK CSÖKKENTÉSÉRE IRÁNYULÓ MAGATARTÁSFORMÁK VIZSGÁLATA
}

\author{
คीด \\ RESEARCH OF RISK REDUCTIVE BEHAVIOURS RELATED TO FOOD PRODUCTS

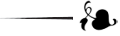 \\ TARI, Katalin \\ LEHOTA, József \\ KoMÁROMI, Nándor

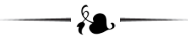

Szent István Egyetem, Gazdaság- és Társadalomtudományi Kar

(Szent István University, Faculty of Economics and Social Sciences)

2100 Gödöllő, Páter Károly utca 1.

e-mail: katalintari@gmail.com

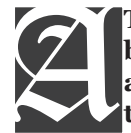

This topic will always be actual, since most of the companies crave to understand the behaviour of their consumers in Hungary - what kind of patterns of behaviour they have, and how companies can influence consumer behaviour without high expenses, considering the most effective methods. As we know, consumer behaviour should be researched on the level of a specific product or service in the short term, or as a brand versus personal preference. Nowadays, the role of health-awareness and cost-consciousness is getting misrated, alongside with environmental protection and the awareness of hazardous substances. Based on our idea, the background of our research assumes awareness of the contents of food, and the investigation of labels or titles. The organic labels on food have a high priority role in Hungary. In our opinion, the trust contains the following factors: (1) There are control authorities who are reliable, and guarantee the high quality of products for the consumers (for example: Hungarian Authority for Consumer Protection, or other food and chemical industrial laboratories). (2) Food processing facilities are accredited, recorded, and given a certificate (for example: certificate of organic production, etc.) (3) Purchasing is straight from the source. (4) Purchase is on the basis of information technology. These factors are the underlying cause of the change in behaviour resulting from risk reduction awareness. The article focuses on the food consumption behaviour analysis of Hungary's population. The analyzed database was queried from IPSOS Ltd. ( $\mathrm{N}=1$ o38 people) but we will select 883 people, based on inclusive criteria (aged between 18 and 70) and exclude people with extreme incomes (due to being outliers). In order to indroduce the topic, we will start our research with a short literary introspection. Before the analysis of the database, we presume consumers have a kind of set awareness that is shaped by buying their daily food and products. In this research, we will prove this assumption.

KULCSSZAVAK: élelmiszer-marketing, élelmiszer-fogyasztói magatartás, csomagoláson található jelölések, társadalmi osztályok
KEYWORDS: food marketing, costumer behaviour based on food sector, markers on the packaging, social-classes

JEL-KóD (JEL CODE): D12 


\section{BEVEZETÉS - INTRODUCTION}

Jelen cikk központi témája a magyar lakosság élelmiszer-fogyasztói magatartásának vizsgálata. A feldolgozott témakör mondhatni, sosem veszti el aktualitását, mivel a legtöbb vállalatnak egyik fö törekvése az, hogy megértse, hogyan viselkednek a vásárlói, továbbá mi alapján hozzák döntéseiket. Mint azt a szakirodalomban, valamint a témához kapcsolódó weboldalakon olvashatjuk, a fogyasztói döntéseket rövidebb távon érdemes konkrét termék, vagy szolgáltatás, illetve márka és egyéni preferencia szintjén vizsgálni. Napjainkban egyre inkább felértékelődött szerepe van az egészségtudatosságnak, a környezetvédelemnek, a károsanyag-kibocsátás mértékének, illetve az élelmiszerek egyre növekvő költségeinek. Modern társadalmunk egyik „betegsége”, hogy egészségünk megóvására egyre többet költünk. Ez egyre több piacot érint az élelmiszeripartól, a gyógyszeriparon át a különböző egészségmegörző szolgáltatásokig (TÖRŐCSIK, 2011). A teljes vásárlói piac tudatos vásárlásra kiterjedő aránya évról évre nő, továbbá - egy lassú folyamat eredményeképp - a közvetlen környezetünk megóvására is kiterjed (lásd az elektromos autók, avagy a szelektív hulladékgyüjtő-pontok növekedésének ütemét).

Kutatásunk hátterében feltételeztük tehát, hogy például az élelmiszerek összetételére való odafigyelés, a felirat, illetve a címke tanulmányozása, avagy a megkülönböztető jelölések (bio-, ökoélelmiszer, származási hely, földrajzi-, eredetjelölés, márka, ellátásilánc-azonosítás, stb.) kiemelt szerepet játszanak a magyar fogyasztó élelmiszer-vásárlási szokásaiban.

A kutatás elsődleges célja, hogy rávilágítson arra, mely információk és tényezók játszanak kiemelt szerepet a magyar lakosság élelmiszerfogyasztásában. További célkitűzés az élelmiszerfogyasztással kapcsolatos kockázatok csökkentésére irányuló magatartásformák mögött meghúzódó tényezők kimutatása, felsorolása és amennyiben a vizsgálat alapján lehetséges, akkor ennek csoportosítása.

A felmérést a Cognative Piackutató Kft. végezte a TAMOP-4.2.1/B-11/2/KMR-20110003 projekten belül 2013-ban. A projekt „Az élelmiszerekhez kapcsolódó észlelt fogyasztói kockázok (élelmiszer, életmód, technológia) és a fogyasztó kockázatcsökkentési alternatívák, valamint a felárfizetési hajlandóság vizsgálata a felnőtt magyar lakosság körében“ elnevezést kapta. A kérdéseket Prof. Dr. Lehota József, valamint a Szent István Egyetem Marketing Intézetének dolgozói állították össze.

A rendelkezésre bocsátott reprezentatív adatbázist ( $\mathrm{N}=1$ 038) az IPSOS Zrt. adta. A mintát a szakirodalomra, valamint a szakmailag indokoltnak vélt tényezókre alapozva tovább szúkítettük, majd így került elemzésre a kutatásban szerepeltetett 883 fó. Beválasztási kritériumunk az önálló jövedelemmel rendelkező személyekre korlátozta a mintát, így a szélsőséges értékek, valamint az önálló jövedelemmel nem rendelkezók kizárása után $\mathrm{N}=883$ fó - 426 férfi $(48,2 \%)$ és 457 nő $(51,8 \%)$ - adatait vettük figyelembe. A megkérdezettek négy korcsoport alapján, illetve az IPSOS Zrt. által használt öt szocióökonómiai felosztás szerint kerültek elkülönítésre. Az elemzés 22 állítás vizsgálatára terjed ki, amely során a magyar lakosság élelmiszer-fogyasztói magatartásának elemzésére és az élelmiszerekkel kapcsolatos kockázatok mérséklésére kivánunk nagyobb hangsúlyt fektetni.

A témakör bemutatását egy rövid irodalmi áttekintéssel folytatjuk.

\section{SZAKIrodalmi ÁTTEKINTÉS -}

\section{Literature REVIEW}

A marketing világában az innovatív megoldásoknak és az új fejlődési lehetőségeknek mindig nagy szerepük lesz. Ezek a versenyképesség javításában éppen úgy nagy szerepet játszanak, mint ahogy a fogyasztók megfelelő igénykielégítésében. Ez pedig állandó kihívást jelent az élelmiszer-fogyasztás területén is, ezért e célcsoport pontos definiálására, továbbá a hatékony marketingkommunikáció megvalósítására kiemelt figyelmet kell szentelni.

A szakirodalomban az élelmiszerfogyasztást meghatározó tényezők után kutatva rengeteg definícióval találkozhatunk, melyek sokszor kisebb-nagyobb átfedésben vannak egymással (HORVÁTH, 2010). A két, általunk leggyakoribbnak ítélt kerül most bemutatásra. Az egyik (CSITE, KOVÁCH és KRISTÓF, 2006) a különböző demográfiai és társadalmi ismérvek, 
az értékrend, az ehhez tartozó kulturális fejlettség, valamint a fogyasztó életstílusa. A második LEHOTA (2004) könyve szerint az élelmiszerfogyasztást közvetlenül a következők határozzák meg:

1. biológiai,

2. pszichológiai,

3. szociológiai,

4. antropológiai,

5. politikai,

6. demográfiai,

7. közgazdasági tényezők.

$\mathrm{Az}$ élelmiszerfogyasztás környezetterhelésének csökkentésére is eltérő lehetőségeket és alternatívákat találunk a világ minden táján, illetve más kultúrákban élő fogyasztók esetében (KOCSIS, 2006).

A társadalmi helyzetnek van a legmeghatározóbb szerepe az élelmiszerfogyasztásban, illetve GOSSARD és YORK (2003) publikációi alapján az egyén szocializációjában, élettapasztalataiban és a pszichológiai jellemzőinek megformálásában. A társadalmi helyzet struktúrált felépítésü, s tényezői határozzák meg azt a környezetet, amiben a pszichológiai tényezők múködnek (VETŐ-MÓZNER, 2014).

Több tanulmány is alátámasztja, hogy szocio-demográfiai tényezók mentén meghatározhatók az élelmiszer-fogyasztási szokások (HULSHOF et al., 1991; SMITH és BAGHURST, 1992; ROOS et al., 1996; JOHANSSON et al., 1999; IRALA-ESTEVEZ et al., 2000; ROOS et al., 2001; DOWLER, 2011), amelyek alapján alapvetően a nem, a kor és a munkavégzés szerint szignifikáns eltérés van az élelmiszerfogyasztásban. HAYN, EMPACHER és HALBES (2005) hét társadalmi-gazdasági tényezőt határoz meg, amelyek hatással lehetnek az élelmiszerfogyasztásra: kor, társadalmi osztály (amelyet a jövedelem és a munkavégzés határoz meg), iskolai végzettség, nem, lakóhely, etnikai hovatartozás és az egyén életmódja. HAYN, EMPACHER és HALBES (2005) definícióit kizárólag a német szakirodalomra és az empirikus kutatásokra alapozta.

A nemek fogyasztása közötti különbséget vizsgálva több tanulmány is megállapítja, hogy szignifikáns különbség van a férfiak és a nők élelmiszer-fogyasztási szerkezetében (PAYER, BURGER és LOREK, 2000; HAYN,
EMPACHER és HALBES, 2005).

A társadalmi marketing a fogyasztók magatartását és befolyásolását vizsgálja, majd ezen magatartást célzó kampányok támogatásával foglalkozik (KOTLER és KELLER, 2006). A jövedelem, mint gazdasági-társadalmi tényező meghatározója az élelmiszerfogyasztásnak. Több tanulmány is alátámasztja, hogy a háztartások árérzékenyek az élelmiszer-vásárlást és ehhez kapcsoltan az élelmiszerfogyasztást tekintve is (HAYN, EMPACHER és HALBES, 2005).

HOFMEISTER-TÓTH, KELEMEN és PISKÓTI (2011) is megállapította, hogy a magyar háztartások fogyasztási mintáit számos tényező határozza meg, például: a jövedelem, a demográfiai változások (több dolgozó nő, több egyszemélyes háztartás, nagyobb a nyugdíjas populáció), valamint az életstílusbeli változások. A bemutatott tényezők ismerete lényeges szempont volt kutatásunk során is.

\section{ANYAg ÉS MÓDSZER -} MATERIAL AND METHOD

A kérdőívezést a Cognative Piac- és Közvéleménykutató Kft. szervezte. A standardizált kérdőívet a bevezetésben is említett, Omnibusz felmérés (SZARKA, LEHOTA és LANGER, 2014) keretein belül kérdezték le, méghozzá face-to-face módszerrel. A kutatás során nyert adatok feldolgozására az IBM SPSS Statistics 21 statisztikai programcsomagot használtuk.

A vizsgálat során elemzett kérdés: „Az élelmiszerekkel kapcsolatos kockázatok csökkentésére, mely magatartásformák jellemzők Önre és családjára?”. A kérdésre 22 állításon, azaz item-en keresztül válaszoltak a megkérdezettek. A kérdés kiválasztása szakmailag megalapozott, mivel a vizsgálat tárgykörét illetően a személyes kérdőív egyik legrelevánsabb kérdése.

A kérdésre adott válaszok leíró statisztikai elemzései során az átlagok, a szórások, valamint a gyakoriságok kerültek feltüntetésre. Az elemzések során létrehozott csoportok, továbbá a köztük lévő különbségek, összefüggések vizsgálata többváltozós statisztikai elemzéssel, fókomponens analízissel, majd klaszterezéssel történt. 


\subsection{A minta jellemzése - Characteristics of Sample}

A felmérésben összesen 1038 fő vett részt, 485 férfi $(46,8 \%)$ és 553 nő (53,2\%). Beválasztási kritériumunk az önálló jövedelemmel rendelkező személyekre korlátozta a mintát, így a szélsőséges értékek, valamint az önálló jövedelemmel nem rendelkezők - 18 éven aluliak - kizárása után $\mathrm{N}=883$ fó adatait vettük figyelembe, akik közül 426 férfi (48,2\%) és 457 nő $(51,8 \%)$ van. A legidősebb válaszadó 70 , míg a legfiatalabb 18 éves. Az átlagéletkor kerekítve 43 év, pontosan 42,65 év.
A mintát a szakirodalomban, valamint további hasonló élelmiszerfogyasztással kapcsolatos kutatások, illetve saját logikai- és szakmailag indokoltnak vélt különbségek alapján három korcsoportra (18-30 év, 31-50 év, 51-70 év) osztottuk. Ezen felosztást, valamint a megkérdezettek úgynevezett „social classes”-be, azaz szocio-ökonómiai osztályba való besorolását az 1. ábra szemlélteti. Ezen szocio-ökonómiai osztályokba való besorolások alapjai közé tartozik a fizetés, a beosztás, a lakhely, egy háztartásra jutó jövedelem, a háztartás műszaki felszereltsége, valamint gyermekeik száma.

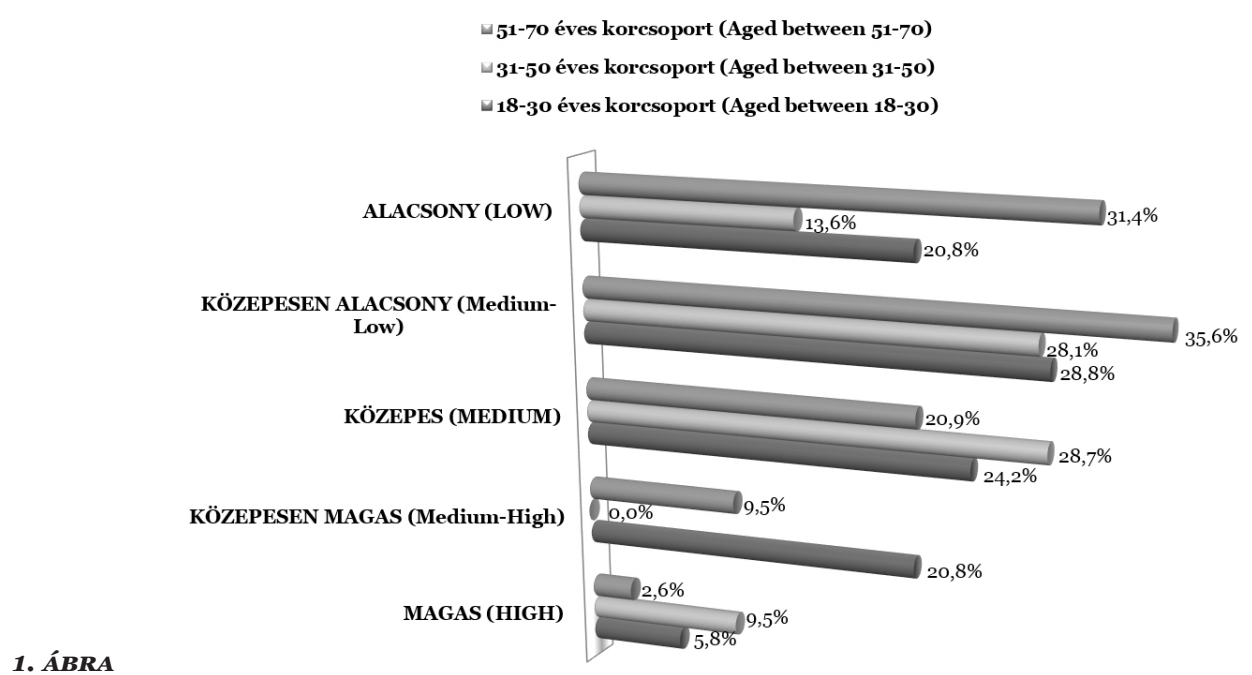

FIG. 1

\section{Korcsoport szerinti megoszlás, $\mathbf{N}=\mathbf{8 8 3}$}

\section{(Division Based on Age Groups and Social-classes, $N=88_{3}$ )}

Forrás (Source): Saját szerkesztés SPSS futtatások során kapott adatok szerint, 2016 (Construction according to own results of SPSS analysis, 2016)

Az 1. ábrán jól látható, hogy a közepes és a közép-alacsony kategóriákban, ezen felül pedig az érett felnőttek között (31-50 éves korig), valamint az 50+ korosztályban (70 éves korig) található a legtöbb válaszadó. Összességében 273 fö, 30,9\% tartozik a közép-alacsony (medium-low) kategóriába. Alapos demográfiai elemzés során láthatóvá vált számunkra az is, hogy ők végzettségben és beosztásban is alacsonyabban kvalifikáltak voltak, illetve háztartásuk felszereltsége is elmaradottabb volt.

A 2. ábrán ismét a közép-alacsony szocio-ökonómiai kategóriába sorolható a legtöbb válaszadó. A nők száma 128 fő (27,8\%), míg a férfiaké 145 fó (34\%). A legmagasabb szocio-ökonómiai besorolásba a megkérdezett nők 5,7\%-a, illetve a férfiak 6,6\%-a tartozik a 883 fős mintát illetően. A további 5 szociális kategória - (1) low: alacsony, (2) medium-low: közepesen alacsony, (3) medium: közepes, (4) medium-high: közepesen magas, (5) high: magas - szerinti összefoglaló eloszlásokat a 2. ábra szemlélteti. A legtöbb megkérdezett a közép-alacsony szociális helyzetű kategóriába tartozik. E csoporton belül a férfiak 34\%-ot, a nők 27,8\%-ot képviselnek. A második legnagyobb értéket a közepes szociális helyzetűek képviselték. A férfiakat a nők követik a harmadik helyen (26,9\%-kal). 


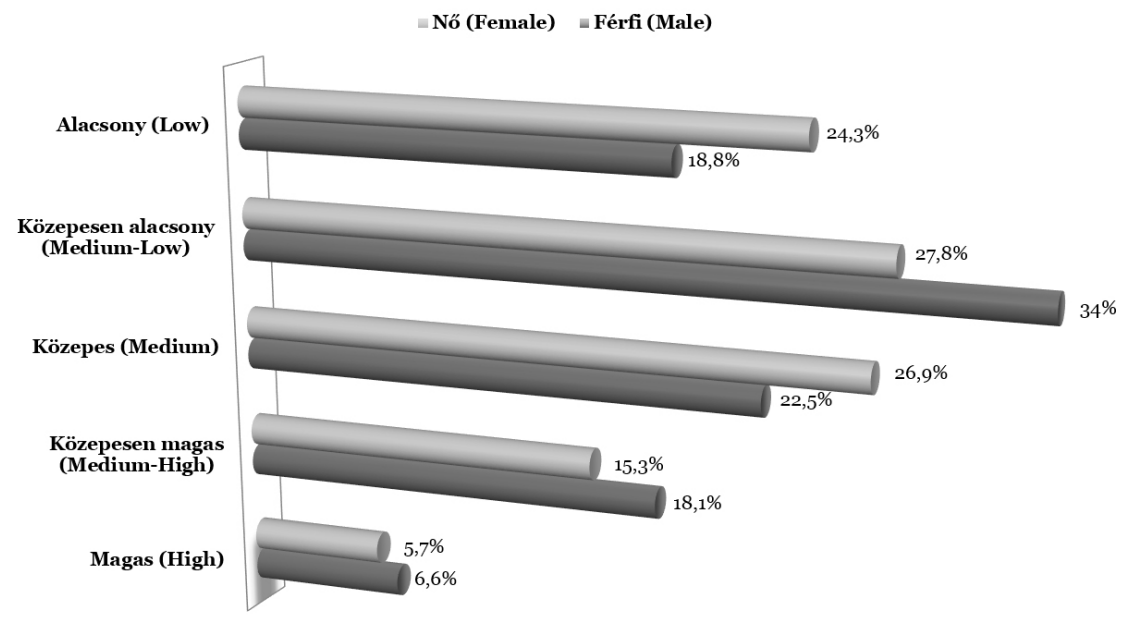

2. ÁBRA

Nemek és szociális helyzet szerinti eloszlás szemléltetése, $\mathbf{N}=\mathbf{8 8 3}$

FIG. 2 (Division Based on Gender and Social-classes, $N=883$ )

Forrás (Source): Saját szerkesztés SPSS futtatások során kapott adatok szerint, 2016 (Construction according to own results of SPSS analysis, 2016)

Mivel a fenti szocio-ökonómiai beosztáshoz szorosan hozzátartozik a fizetés mértéke, a lakhely, továbbá a foglalkozás, illetve a beosztás is, ezért a teljesség igénye nélkül szemléltetjük a következő táblázatokban ezen adatokat is, amely a szociális beosztás alapját képezte.

$\mathrm{Az}$ átlagos havi nettó jövedelemre vonatkozó kérdésre a 883 fóból 615 fó válaszolt a személyes megkérdezés során. Ennek oka feltételezhetően részben az volt, hogy nem in- tervallum skála volt megadva, hanem nyílt kérdésre, pontos adatokat megadva kellett válaszolniuk a fogyasztóknak. Ezáltal kutatói szemmel könnyebben, pontosabban mérhetőek az adatok. Ezzel szemben ez a fajta személyes megkérdezés, valamint válaszadási mód csökkenti leginkább a válaszadási hajlandóságot - ezen csökkenésről felmérések alapján több helyen említést tesznek - amely esetünkben is láthatóvá vált (615 fó) (1. táblázat).

(Net Income Data, $N=615$ )

\begin{tabular}{lccccc}
\hline & N & Min & Max & $\begin{array}{c}\text { Átlag } \\
\text { (Mean) }\end{array}$ & $\begin{array}{c}\text { Szórás (Std. } \\
\text { Deviation) }\end{array}$ \\
\hline $\begin{array}{l}\text { Megmondaná, mennyi az Önök háztartásának átla- } \\
\text { gos havi nettó jövedelme összesen? (Could you say } \\
\text { how much the net income is in your family?) }\end{array}$ & 615 & 22000 & 2500 ooo & 164370,10 & 117172,89 \\
\hline
\end{tabular}

Forrás (Source): Saját szerkesztés SPSS futtatások során kapott adatok szerint, 2016 (Construction according to own results of SPSS analysis, 2016) 
TARI, K. - LEHOTA, J. - KOMÁROMI, N.

A lakhelytípusok 4 csoportba - Budapest, nagyváros, kisváros, falu - lettek besorolva a településhálózatban betöltött szerepük és a lakosságszám alapján, melyet a 3. ábra szemléltet, kerekített értékekkel. Legtöbben, 288 fövel, 32,7\%-kal faluban laknak, majd őket a kisvárosiak követik 254 fővel, azaz 28,8\%-kal. A

harmadik csoport 167 fővel, 18,9\%-kal a nagyvárosiak és a legkisebb csoportot a budapestiek alkotják 174 fővel, 19,7\%-kal. Összefoglalva tehát a mintában a faluhelyen élők vannak a legtöbben (32\%), majd a kisvárosiak (19\%), harmadik helyen pedig a budapestiek.

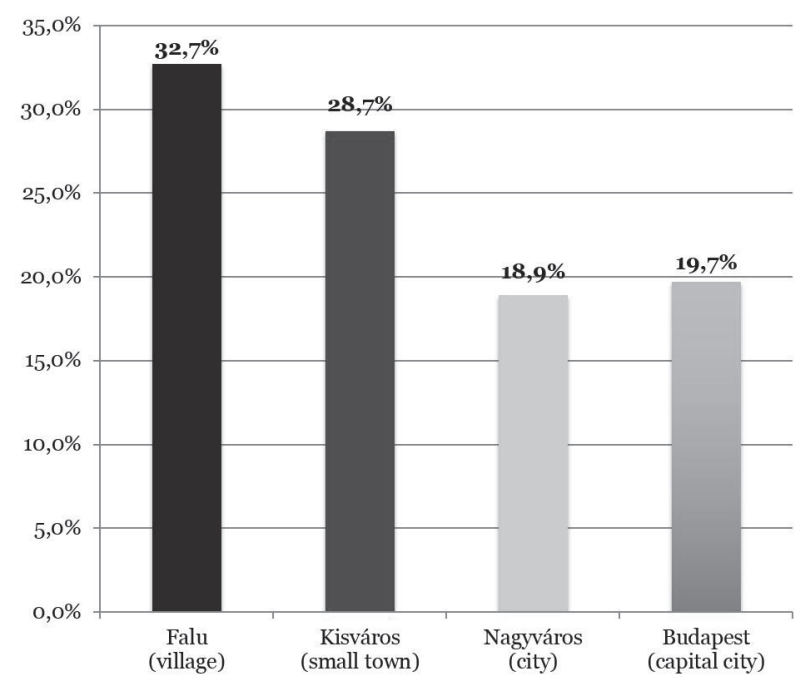

3. ÁBRA

Lakhely-besorolás, valamint azok eloszlása a Cognative Piackutató $\mathrm{Kft}$. által elvégezett OMNIBUSZ kutatás kategorizálása alapján, $\mathbf{N}=883$

(Residency Classification and Distribution According to Classification Categories in the "OMNIBUSZ" Research, $N=883$ )

Forrás (Source): Saját szerkesztés SPSS futtatások során kapott adatok szerint, 2016 (Construction according to own results of SPSS analysis, 2016)

TAMOP-4.2.1/B-11/2/KMR-2011-OOO3 projekt, a kérdések összeállítását a Szent István Egyetem dolgozói végezték, 2013 (Research made by "Cognative Piackutató" Ltd. in the project with the researcher of Szent István Univesity under the name of "TAMOP-4.2.1/B-11/2/KMR-2011-OOO3“, 2013) 


\section{EredményeK - Results}

\subsection{Főkomponens analízis - Principal Component Analysis}

Az adott kérdéskör vizsgálatára 22 állítást, azaz item-et tartalmazott az OMNIBUSZ kutatás. Ezen állításokon végeztünk fókomponens-analízist, ezt követően pedig klaszterelemzést.

Az elemzés eredményeképp 4 fókomponenst különítettünk el a leadott válaszok elemzése alapján. Mivel a 4. fókomponens szakmai tartalma nehezen volt megállapítható, ezért a tisztább struktúra, azaz az egyértelmúbb besorolás elérése érdekében a Varimax rotálást alkalmaztuk, melyet a 3. táblázat szemléltet. A fókomponensek a teljes információ-tartalom 53,52\%-át magyarázzák.

A $2{ }_{a}$ és $2_{b}$ táblázatban - „Az élelmiszerekkel kapcsolatos kockázatok csökkentésére, mely magatartásformák jellemzők Önre és családjára?" - látható fókomponensek a teljes információtartalomnak az 53,5\%-át magyarázzák.

$\mathrm{Az}$ állítások tartalma alapján a meghatározott 4 fókomponens elnevezése - a szerzők szakmailag megalapozott tapasztalatának segítségével - a következőképpen került kialakításra:

1. Független, külső hatóság megítélése alapján történő vásárlás

2. Jelölés alapján történő vásárlás (biovagy ökoélelmiszer jelölés, gyártó, termelő, címke, nagy termelő, szezonalitás, stb.)

3. Beszerzési forrásba vetett bizalom alapján történő vásárlás

4. Élelmiszer-technológia alapján történó vásárlás

Ezt követően klaszteranalízist végeztünk annak érdekében, hogy részletesebben elemezhetővé váljon a 883 fős minta.

2 TÁBLÁZAT

TABLE 2

A rotált fókomponens mátrix értékei állításcsoportok jelölésével, Készült a Cognative

Piackutató Kft. által elvégezett OMNIBUSZ kutatás eredményei alapján, N=883

(Rotated Component Matrix in Statements According to Data of "OMNIBUSZ" Research, $N=88_{3}$ )

\begin{tabular}{|c|c|c|c|c|}
\hline \multirow[t]{2}{*}{ Állítások (Statements) } & \multicolumn{4}{|c|}{$\begin{array}{c}\text { Fókomponensek súlyozása alapján } \\
\text { kialakított állításcsoportok (Groups of } \\
\text { the Components) }\end{array}$} \\
\hline & 1 & 2 & 3 & 4 \\
\hline $\begin{array}{l}\text { Bízok a hatóságok gyors és hatékony élelmiszer visszavonási (gyors } \\
\text { riasztási rendszerében, piacról való kivonás, megsemmisítés) } \\
\text { rendszerében (Trust in the food control system’s efficient work } \\
\text { (fast control and alarm system, withdrawals of problematic, poisoned, } \\
\text { non-controlled, etc. food) and annulment) }\end{array}$ & 0,773 & 0,126 & 0,174 & 0,152 \\
\hline $\begin{array}{l}\text { Bízok az élelmiszerellenőrző hatóságok élelmiszerkockázatot csökkentő } \\
\text { tevékenységében (Trust in the food control authorities' activities to } \\
\text { reduce food risks) }\end{array}$ & 0,772 & 0,065 & 0,182 & 0,247 \\
\hline $\begin{array}{l}\text { Bízok a magyar növény és állategészségügyi hatóságok ellenőrzéseiben } \\
\text { (Trust in Hungarian plant and animal health authorities) }\end{array}$ & 0,762 & 0,078 & 0,214 & 0,160 \\
\hline $\begin{array}{l}\text { Bízok az élelmiszerlánc (termelő, feldolgozó és kereskedő) } \\
\text { termékazonosítási és nyomon követési rendszerében (Trust in the food } \\
\text { chain (production, processing and trading) product identification and } \\
\text { tracking system) }\end{array}$ & $0,75^{2}$ & 0,103 & 0,171 & 0,191 \\
\hline $\begin{array}{l}\text { Egyre több információt szerzek az élelmiszerekról (orvosok, } \\
\text { dietetikusok, folyóiratok, internet) (I get more and more information } \\
\text { about food (doctors, dietitians, magazines, Internet)) }\end{array}$ & $-0,019$ & 0,687 & 0,088 & 0,240 \\
\hline $\begin{array}{l}\text { Megváltoztatom az élelmiszerfogyasztási szokásaimat ( I change my } \\
\text { habits of food consumption) }\end{array}$ & $-0,028$ & 0,684 & $-0,135$ & 0,254 \\
\hline $\begin{array}{l}\text { Bio és öko-élelmiszereket vásárolok (I prefer to buy from bio- or } \\
\text { organic producers) }\end{array}$ & 0,056 & 0,646 & $-0,014$ & 0,278 \\
\hline $\begin{array}{l}\text { Ipari, gyártói márkás élelmiszereket vásárolok (I prefer to buy } \\
\text { manufacturer branded foods) }\end{array}$ & 0,340 & 0,605 & 0,158 & 0,018 \\
\hline
\end{tabular}


A rotált fökomponens mátrix értékei állításcsoportok jelölésével, Készült a Cognative Piackutató Kft. által elvégezett OMNIBUSZ kutatás eredményei alapján, N=883

(Rotated Component Matrix in Statements According to Data of "OMNIBUSZ" Research, $N=883$ )

\begin{tabular}{|c|c|c|c|c|}
\hline \multirow[t]{2}{*}{ Állítások (Statements) } & \multicolumn{4}{|c|}{$\begin{array}{c}\text { Fókomponensek súlyozása alapján } \\
\text { kialakított állításcsoportok (Groups of } \\
\text { the Components) }\end{array}$} \\
\hline & $\mathbf{1}$ & 2 & 3 & 4 \\
\hline $\begin{array}{l}\text { Figyelem az élelmiszercímkéken felsorolt terméktulajdonságokat (I pay } \\
\text { attention to the product characteristics listed on food labels) }\end{array}$ & 0,121 & 0,576 & 0,274 & 0,071 \\
\hline $\begin{array}{l}\text { Kereskedelmi márkás élelmiszereket vásárolok (pl. Tesco, Spar) } \\
\text { (I usually buy supermarket own brand food (eg. Tesco, Spar)) }\end{array}$ & 0,415 & 0,490 & 0,068 & $-0,136$ \\
\hline $\begin{array}{l}\text { Földrajzi és eredetjelölt élelmiszereket vásárolok (I like to buy goods } \\
\text { that are labelled correctly with geographic origin) }\end{array}$ & 0,193 & 0,387 & 0,371 & 0,373 \\
\hline $\begin{array}{l}\text { Rendszeresen a megszokott boltban vásárolok (I usually go shopping to } \\
\text { the same shop) }\end{array}$ & 0,268 & $-0,027$ & 0,669 & $-0,079$ \\
\hline $\begin{array}{l}\text { A helyi termelőktól és feldolgozóktól vásárolok, nem pedig távolról } \\
\text { szállított élelmiszereket (I buy from local producers and } \\
\text { processors, rather than food shipped from abroad) }\end{array}$ & $-0,012$ & 0,371 & 0,608 & 0,346 \\
\hline $\begin{array}{l}\text { A magyar élelmiszereket előnyben részesítem a külföldiekkel szemben } \\
\text { (Hungarian food is preferred instead of food of foreign origin) }\end{array}$ & 0,229 & $-0,035$ & 0,604 & 0,231 \\
\hline $\begin{array}{l}\text { Szezonális élelmiszereket vásárlok és fogyasztok (I buy and consume } \\
\text { seasonal food) }\end{array}$ & 0,189 & 0,238 & 0,583 & 0,100 \\
\hline $\begin{array}{l}\text { A termelőtől és a gyártótól közvetlenül vásárolok (I like to buy directly } \\
\text { from a producer and/or a manufacturer) }\end{array}$ & $-0,109$ & 0,484 & 0,568 & 0,105 \\
\hline $\begin{array}{l}\text { Nem vásárolok élelmiszereket illegális vagy gyanúsan olcsó forrásból } \\
\text { (I do not buy cheap groceries from any illegal or suspicious sources) }\end{array}$ & 0,407 & $-0,087$ & 0,531 & 0,155 \\
\hline $\begin{array}{l}\text { A hagyományos technológiával előállított élelmiszereket részesítem } \\
\text { előnyben (I prefer food produced in a conventional way) }\end{array}$ & 0,229 & $-0,025$ & 0,510 & 0,421 \\
\hline $\begin{array}{l}\text { Előnyben részesítem azokat az élelmiszereket, amelyeknek előálítása } \\
\text { alacsony vízfelhasználást igényel (I prefer food produced in a way that } \\
\text { requires less water) }\end{array}$ & 0,243 & 0,247 & 0,080 & 0,707 \\
\hline $\begin{array}{l}\text { Előnyben részesítem azokat az élelmiszereket, amelyeknek előállítása } \\
\text { alacsony széndioxid kibocsátást igényel (I prefer food produced in a } \\
\text { way that results in low carbon dioxide emissions) }\end{array}$ & 0,195 & 0,186 & 0,121 & 0,691 \\
\hline $\begin{array}{l}\text { Előnyben részesítem a nem nagyüzemi körülmények között } \\
\text { előállított termékeket (I prefer products that are not produced under } \\
\text { any industrial conditions) }\end{array}$ & 0,098 & 0,246 & 0,361 & 0,508 \\
\hline $\begin{array}{l}\text { Jobban elókészítem és megszervezem a vásárlásaimat (I like to prepare } \\
\text { and organize my purchases) }\end{array}$ & 0,278 & 0,248 & 0,332 & 0,422 \\
\hline
\end{tabular}

Forrás (Source): Saját szerkesztés SPSS futtatások során kapott adatok szerint, 2016 (Construction according to own results of SPSS analysis, 2016)

A fókomponens elemzés Varimax rotációval, Kaiser normalizáció, rotáció során az iterációk száma 7. (Extraction Method: Principal Component Analysis; Rotation Method: Varimax with Kaiser Normalization; Rotation converged in 7 iterations)

TAMOP-4.2.1/B-11/2/KMR-2011-0003 projekt, a kérdések összeállítását a Szent István Egyetem dolgozói végezték, 2013 (Research made by "Cognative Piackutató" Ltd. in the project with the researcher of Szent István Univesity under the name of "TAMOP-4.2.1/B-11/2/KMR-2011-OOO3“, 2013, $N$ = 883)) 


\subsection{Klaszteranalízis - Cluster Analysis}

A fenti fókomponensek alapján elvégzett klaszteranalízis eredményeképp a 4. főkomponens az élelmiszer-technológiai információk alapján történő vásárlás figyelembe vétele - a modellben nem szerepel, a statisztikai elemzés alap- ján nem szignifikáns változó $(\mathrm{F}(2,706)=2,154$, $\mathrm{p}=0,117)$. Említettük, hogy a 4. főkomponens szakmai tartalma már a fókomponens analízis eredményeit illetően sem volt egyértelmü.

Az egyes klaszterekhez tartozó végső klaszterközéppontokat a fennmaradt 3 fökomponens esetében a 3. táblázat tartalmazza.

A klaszterekhez tartozó végső klaszterközéppontok (Results of the Cluster Analysis)

\begin{tabular}{lcccc}
\hline & \multicolumn{4}{c}{ Klaszterek (Clusters) } \\
\cline { 2 - 4 } & $\mathbf{1}(\mathbf{N}=\mathbf{3 0 1})$ & $\mathbf{2}(\mathbf{N}=\mathbf{8 9})$ & $\mathbf{3}(\mathbf{N = 2 5 4 )}$ & $\mathbf{4}(\mathbf{N = 1 3 5 )}$ \\
\hline $\begin{array}{l}\text { 1. fókkomponens } \\
\text { (1st component) }\end{array}$ & 0,38522 & $-1,28486$ & $-0,61285$ & 0,99009 \\
\hline $\begin{array}{l}\text { 2. fókomponens } \\
\text { (2nd component) }\end{array}$ & 0,70184 & $-0,72725$ & 0,12597 & $-1,24742$ \\
\hline $\begin{array}{l}\text { 3. fókomponens } \\
\text { (3rd component) }\end{array}$ & 0,39188 & 1,18255 & $-0,87008$ & $-0,09577$ \\
\hline
\end{tabular}

Forrás (Source): Saját szerkesztés SPSS futtatások során kapott adatok szerint, 2016 (Construction according to own results of SPSS analysis, 2016)

A 3 fókomponens egyes klaszterekre jellemző végső klaszterközéppontjai alapján kibontakozik egy olyan kép, amely szerint az 1 . klaszterbe tartozó válaszadók vásárlási attitűdjét több tényező is jelentősen meghatározza. Ezek a független, külső hatóság megítélése alapján történő vásárlás, a jelölési információk figyelembe vétele, valamint a beszerzési forrásba vetett bizalom. A 3 fókomponens, illetve a 2. klaszterbe tartozó válaszadók értékei megmutatják, hogy az ebbe a klaszterbe tartozó tagok elsősorban a beszerzési forrásba vetett bizalmukat helyezik előtérbe az élelmiszer-bevásárlásuk során. Ezen túlmenően a 3. klaszter vásárlási attitűdjeit az 1. klaszterhez hasonlóan mind a három tényező meghatározza, de csak közepes (bizonytalan) mértékben. E klaszter esetében feltételezhető, hogy más tényezők határozzák meg az élelmiszerfogyasztást, amely a jövőben további vizsgálat tárgykörét képezheti. A 4. klaszter vásárlási attitűdjét elsősorban a független, külső hatóság megítélése alapján történő vásárlás határozza meg, a másik 2 „információforrás" csak másodlagos.

További vizsgálatainkat a 4. táblázat szemlélteti, amely a számolt varianciaanalízis eredményeit tartalmazza. A p-értékeit - empirikus szignifikancia szintjeit - figyelve látható, hogy a 4 klaszter egymástól statisztikailag szignifikáns mértékben is különbözik - megvizsgálva az egyes fókomponenseket.

Itt érdemes említést tenni egy, a kutatási eredményeket - feltételezetten - negatívan befolyásoló, torzító tényezőról, amely a beválasztási kritériumok bevezetése miatt jelentkezhet (lásd 80. oldal). Éppen ezért a teljesség igénye érdekében került ugyanígy elemzésre a teljes, reprezentatív adatbázis $(\mathrm{N}=1038)$ is. Ekkor szintén 4 az élelmiszerekkel kapcsolatos kockázatok csökkentésére irányuló magatartásforma jelent meg. Az első 3 főkomponens váltózócsoportjainak állítástartalma az első kettőnél szinte maradéktalanul megegyezett (1. Független, külső hatóság megítélése alapján, 2. Jelölés alapján történő vásárlás). A beszerzési forrásba vetett bizalom alapján történő vásárlás szintén több egyezőséget mutatott, de megközelítőleg csupán 80\%-ban. A klaszteranalízis során kapott eredmények szerint a 4. fókomponens (élelmiszer-technológia alapján történő vásárlás) alig 40\%-os egyezőséget mutatott az állításcsoportok változóit figyelve. Azonban a 4. főkomponenst - a már korábban leírt eredmények alapján - nem szerepeltettük a modellünkben. 
Varianciaanalízis eredménye a vizsgált 4 klaszterváltozó és a 3 fökomponens esetében (Result of ANOVA with 4 Cluster Variables and with 3 Components)

\begin{tabular}{|c|c|c|c|c|c|c|c|c|c|c|c|}
\hline & \multicolumn{2}{|c|}{$\begin{array}{c}\text { 1. klaszter, } \\
\mathrm{N}=301 \\
\text { (1st Cluster, } \\
\mathrm{N}=\mathbf{3 0 1} \text { ) }\end{array}$} & \multicolumn{2}{|c|}{$\begin{array}{l}\text { 2. klaszter, } \\
\mathrm{N}=89 \\
\text { (2nd Cluster, } \\
N=89)\end{array}$} & \multicolumn{2}{|c|}{$\begin{array}{c}\text { 3. klaszter, } \\
\mathrm{N}=254 \\
(3 r d \text { Chister, } \\
N=254)\end{array}$} & \multicolumn{2}{|c|}{$\begin{array}{l}\text { 4. klaszter, } \\
\mathrm{N}=135 \\
\text { (4th Cluster, } \\
\text { N=135) }\end{array}$} & \multirow[b]{2}{*}{ 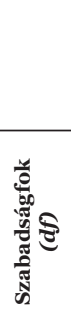 } & \multirow[b]{2}{*}{$\mathbf{F}$} & \multirow[b]{2}{*}{$\mathbf{p}$} \\
\hline & 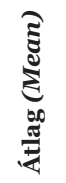 & 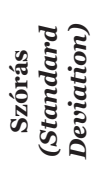 & 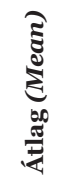 & 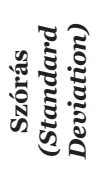 & 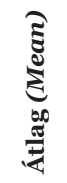 & 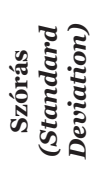 & 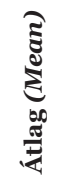 & 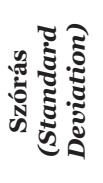 & & & \\
\hline $\begin{array}{l}\text { 1. fö-komponens } \\
\text { (1st component) }\end{array}$ & 4,25 & 0,507 & 2,93 & 0,750 & 3,23 & 0,555 & 4,43 & 0,603 & 3,705 & 227,99 & $<0,01$ \\
\hline $\begin{array}{l}\text { 2. fö-komponens } \\
\text { (2nd component) }\end{array}$ & 3,80 & 0,448 & 2,66 & 0,743 & 3,03 & 0,584 & 2,48 & 0,511 & 3,705 & 261,76 & $<0,01$ \\
\hline $\begin{array}{l}\text { 3. fö-komponens } \\
\text { (3rd component) }\end{array}$ & 4,24 & 0,401 & 4,22 & 0,538 & 3,25 & 0,516 & 3,77 & 0,646 & 3,705 & 191,73 & $<0,01$ \\
\hline
\end{tabular}

Forrás (Source): Saját szerkesztés SPSS futtatások során kapott adatok szerint, 2016 (Construction according to own results of SPSS analysis, 2016)

- 1. fökomponens (1st Component) $\quad$ 2. fókomponens (2nd Component) $\quad 3$. fókomponens (3rd Component)

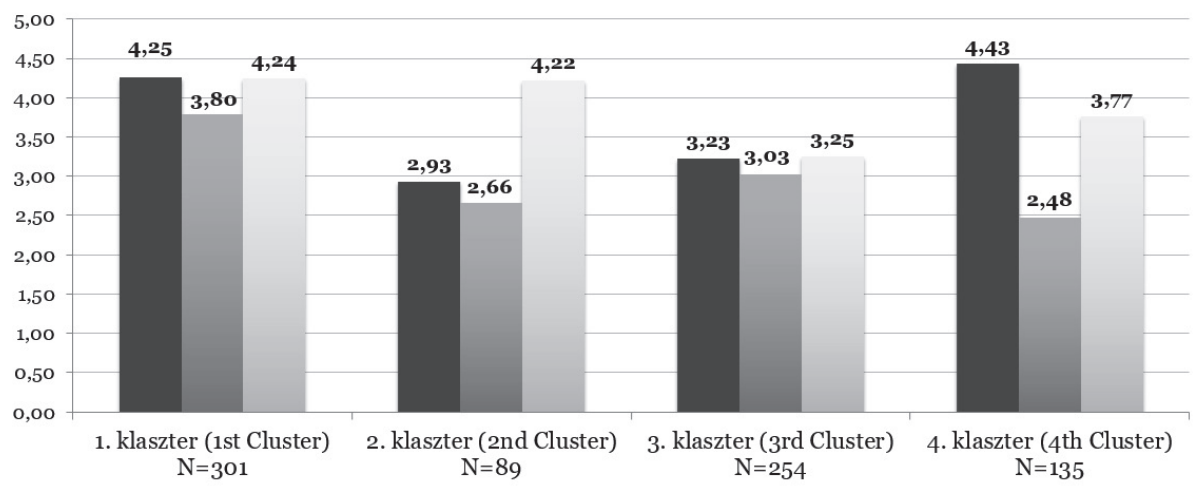

4. ÁBRA

A 4 klaszter átlagértékei az egyes fökomponensekben

FIG. 4 (Means of Four Clusters in Components)

Forrás (Source): Saját szerkesztés SPSS futtatások során kapott adatok szerint, 2016 (Construction according to own results of SPSS analysis, 2016)

3.3. Klaszterek életkor-csoportok, nemi és szocio-ökonómiai különbségei Differences between Clusters Based on Age, Gender and Social-classes

Az egyes szocio-ökonómiai arányokat „A klasztercsoportok elemzése szocio-ökonómiai státusz alapján” az 5. táblázat tartalmazza, amelyek statisztikailag szignifikáns különbséget mutattak a 4 klaszterben $\left(\chi^{2}(12)=45,060\right.$, $\mathrm{p}<0,001)$. Az első klaszter a „leggazdagabb” a
4 klaszter közül, a személyek 57,6\%-a a közepes, közepesen magas és magas szocio-ökonómiai csoportba tartoznak. A negyedik klaszter a „legszegényebb”, ahova a személyek 39,7\%-a tartozik. A negyedik klaszterben a legmagasabb (33,6\%) az alacsony szocio-ökonómiai csoportba tartozók aránya a másik három klaszterhez viszonyítva. A második és harmadik klaszter esetében a személyek 52,5\%-a, illetve 45\%-a tartozik a felső három (magas, közepesen magas, közepes) szocio-ökonómiai besorolásba. 
A klaszterekcsoportok elemzése szocio-ökonómia státuszuk alapján, \%

TABLE 5 (Cluster Analysis Based on Social-classes, \%)

\begin{tabular}{lcccc}
\multicolumn{1}{c}{$\begin{array}{c}\text { Szocio-ökonómiai státuszok } \\
\text { (Social-economic Statuses) }\end{array}$} & \multicolumn{4}{c}{ Klaszterek (Clusters) } \\
\cline { 2 - 6 } & $\mathbf{1}(\mathbf{N = 2 7 8 )}$ & $\mathbf{2}(\mathbf{N = 8 0})$ & $\mathbf{3}$ (N=219) & $\mathbf{4}$ (N=131) \\
\hline Magas (High) & 8,6 & 1,2 & 5,0 & 7,6 \\
\hline Közepesen magas (Medium high) & 17,3 & 23,8 & 19,6 & 14,5 \\
\hline Közepes (Medium) & 31,7 & 27,5 & 20,5 & 17,6 \\
\hline Közepesen alacsony (Medium low) & 28,1 & 33,8 & 38,8 & 26,7 \\
\hline Alacsony (Low) & 14,4 & 13,8 & 16,0 & 33,6 \\
\hline
\end{tabular}

Forrás (Source): Saját szerkesztés SPSS futtatások során kapott adatok szerint, 2016 (Construction according to own results of SPSS analysis, 2016)

A klaszterek életkor-csoportok szerinti arányait a 6. táblázatban szemlélteti, ahol a 4 klaszterben statisztikailag szignifiáns mértékben nem különbözött az egyes életkor-csoportok aránya $\left(\chi^{2}=7,378, p=0,287\right)$ A 18-30, 31-50, 51-70 éves korcsoportba tartozók aránya mind a 4 klaszter esetében közel azonos eloszlású volt.

A 4. klaszterhez tartozó nemek aránya a 7. táblázatban látható. A klaszterek és nemek arányának varianciaanalízise szignifikáns el- térést mutat $\left(\chi^{2}=8,881, p=0,031\right)$, azonban az egyes klaszterekben a nemek arányát megvizsgálva, szakmailag a jelentôs eltérés megkérdőjelezhető.

A bevezetésben már tárgyalt témakör volt a nemek fogyasztása közötti különbség. Korábbi tanulmányok beszámoltak szignifikáns eredményekről, a férfiak és a nők élelmiszer-fogyasztási szerkezetét vizsgálva (PAYER, BURGER és LOREK 2000; HAYN, EMPACHER és HALBES, 2005).

Klaszterek korcsoportok szerinti vizsgálata, \% (Clusters Based on Different Age Groups, \%)

\begin{tabular}{lccccc}
\hline \multirow{2}{*}{ Korcsoportok (Age Groups) } & \multicolumn{4}{c}{ Klaszterek (Clusters) } \\
\cline { 2 - 6 } & $\mathbf{1}(\mathbf{N = 2 7 8 )}$ & $\mathbf{2}(\mathbf{N = 8 0})$ & $\mathbf{3}(\mathbf{N = 2 1 9 )}$ & $\mathbf{4}(\mathbf{N = 1 3 2})$ \\
\hline 18-30 év (Age 18-30) & 27,4 & 18,8 & 29,1 & 27,3 \\
\hline 31-50 év (Age 31-50) & 37,9 & 43,8 & 42,3 & 34,1 \\
\hline 51-70 évesek (Age 51-70) & 34,7 & 37,5 & 28,6 & 38,6 \\
\hline
\end{tabular}

Forrás (Source): Saját szerkesztés SPSS futtatások során kapott adatok szerint, 2016 (Construction according to own results of SPSS analysis, 2016)

7. TÁBLÁZAT

TABLE 7

Az adott élelmiszer-fogyasztói minta nemek szerinti összetétele a 4 klaszterben, \% (The 4 Clusters Based on Gender, \%)

\begin{tabular}{lccccc}
\hline \multirow{2}{*}{ Válaszadó neme (Gender) } & \multicolumn{4}{c}{ Klaszterek (Clusters) } \\
\cline { 2 - 6 } & $\mathbf{1}(\mathbf{N}=\mathbf{2 7 8})$ & $\mathbf{2}(\mathbf{N = 8 0})$ & $\mathbf{3}(\mathbf{N}=\mathbf{2 1 9})$ & $\mathbf{4}(\mathbf{N}=\mathbf{1 3 2})$ \\
\hline Férfi (Male) & 43,2 & 60,0 & 52,3 & 51,5 \\
\hline Nő (Female) & 56,8 & 40,0 & 47,7 & 48,5 \\
\hline
\end{tabular}

Forrás (Source): Saját szerkesztés SPSS futtatások során kapott adatok szerint, 2016 (Construction according to own results of SPSS analysis, 2016) 


\section{KöVETKEZTETÉSEK ÉS}

\section{JAVASLATOK - CONCLUSIONS AND SUGGESTIONS}

Jelen kutatásban elemzésre kerültek az élelmiszerekkel kapcsolatos kockázatok csökkentésére irányuló magatartásformák. A vizsgált kérdéskör alapján szakmailag megalapozott állításokat választottunk ki, és azokat elemeztük. A kérdés az „élelmiszerekkel kapcsolatos kockázatok csökkentésére irányuló magatartásformák" vizsgálatára irányult.

Az 1. fókomponens a független, külső hatóság megítélése alapján történő vásárlási magatartásformák köré épül. A főkomponens változóit az információszerzési igény és a független hatósági, valamint ellenőrző hatóságok felé tanúsított bizalom jellemzi leginkább. Elóbbi informálódás - az állítás alapján - az ellátásilánc termékazonosítási és nyomonkövetési rendszerére terjed ki. A magyar élelmiszer-fogyasztók bizalmi köréból kikerülni relatíve könnyü. A bizalom megtartásának alappilléreit esetünkban a független, hazai és nemzetközi szinten is aktív, gyors, továbbá hatékony összeköttetésben alkalmazott, hitelesített rendszerek, ellenőrző hatóságok, élelmiszer-ellenőrző szervek, valamint magyar növény- és állategészségügyi hatóságok megfelelő múködése adja. Ezen főkomponenshez tartozó állítások:

- Bízok a hatóságok gyors és hatékony élelmiszer-visszavonási (gyors riasztási rendszer, piacról való kivonás, megsemmisítés) rendszerében.

- Bízok az élelmiszerellenőrző hatóságok élelmiszerkockázatot csökkentő tevékenységében.

- Bízok a magyar növény- és állategészségügyi hatóságok ellenőrzéseiben.

- Bízok az élelmiszerlánc (termelő, feldolgozó és kereskedő) termékazonosítási és nyomonkövetési rendszerében.

A 2. fókomponens a jelölés alapján történő vásárlási magatartásformákat tartalmazza. Ezen főkomponens változóit szintén meghatározza a magyar élelmiszer-fogyasztók információszerzési igénye, ezúttal azonban elsősorban egészségtudatosságukra irányulva jelenik meg. A változót meghatározza ezen felül a jelölésre, a címkére, a márkára, a közvetlen termelőtől/ gyártótól történő vásárlásra, az egészségtudatosságra, valamint a földrajzi elhelyezedésre és eredetjelölésre irányuló figyelem. A bizalom második alappillére esetünkben a megfeleló informálás biztosítása, a beazonosíthatóság, a visszaellenőrizhetőség, a földrajzi és az eredetjelölés köré épül. Ezek a hatékony ellenőrző-, valamint független hatósági szervek, továbbá az élelmiszerek ellenőrzését kontrolláló rendszerek és hatóságok múködései lehetnek. A 2. fókomponenshez tartozó állítások:

- Egyre több információt szerzek az élelmiszerekről (orvosok, dietetikusok, folyóiratok, internet).

- Megváltoztatom az élelmiszerfogyasztási szokásaimat.

- Bio- és öko-élelmiszereket vásárolok.

- Ipari, gyártói márkás élelmiszereket vásárolok.

- Figyelem az élelmiszercímkéken felsorolt terméktulajdonságokat.

- Kereskedelmi márkás élelmiszereket vásárolok. (pl. Tesco, Spar)

- Földrajzi és eredetjelölt élelmiszereket vásárolok.

A 3. fókomponens a beszerzési forrásba vetett bizalom alapján történő vásárlási magatartásformákat tartalmazza. A megfelelő beszerzési forrás bizalmi elemei közé tartoznak a helyi, illetve a hazai termelók felé tanúsított megbízhatóság és a magyarországi igényeket kielégító minősége. Továbbá a termelő és a gyártó elérhetősége és az általuk elóállított, hasonló minőségú élelmiszerek biztosítása, illetve az ismert és hagyományos technológiák alkalmazása is. A beszerzési forrásba vetett bizalomhoz tartoztak még a megszokás, a szezonalitás, az ár és minőség kapcsolata köré csoportosuló vásárlási magatartásformák is. Az 3. fókomponenshez tartozó állítások:

- Rendszeresen a megszokott boltban vásárolok.

- A helyi termelőktől és feldolgozóktól vásárolok, nem pedig távolról szállított élelmiszereket.

- A magyar élelmiszereket előnyben részesítem a külföldiekkel szemben.

- Szezonális élelmiszereket vásárlok és fogyasztok.

- A termelőtôl és a gyártótól közvetlenül vásárolok. 
- Nem vásárolok élelmiszereket illegális vagy gyanúsan olcsó forrásból.

- A hagyományos technológiával előállított élelmiszereket részesítem előnyben.

A 4. fókomponensben található a legalacsonyabb elemszámú minta, tehát ezeket az állításokat jelölték be legkevesebben. Az élelmiszer-technológia alapján történő vásárlási magatartásformák elsősorban a magyar élelmiszer-fogyasztók környezettudatosságára vonatkoznak. Az élelmiszerek előállítása során felhasznált víz mennyiségének figyelembe vétele, valamint a kisebb üzemekben előállított termékek vásárlással történő támogatása is lényeges szempont, mely magasabb információs szükségletként hat a hazai élelmiszer-fogyasztóra. Ezen komponens kizárásra került, így a következtetések bővebb kifejtését elvetettük. Ezen túlmenően a 4. főkomponenshez tartozik a vásárló felkészültségére, valamint a vásárlás megszervezésére vonatkozó állítás is. A 4. főkomponens item-einek tartalma:

- Előnyben részesítem azokat az élelmiszereket, amelyeknek előállítása alacsony vízfelhasználást igényel.

- Előnyben részesítem azokat az élelmiszereket, amelyeknek előállítása alacsony széndioxid kibocsátást igényel.

- Előnyben részesítem a nem nagyüzemi körülmények között előállított termékeket.

- Jobban előkészítem és megszervezem a vásárlásaimat.

A 3 főkomponens egyes klaszterekre jellemző végső klaszterközéppontjai alapján egy olyan kép bonatkozik ki, mely szerint az 1. klaszter elemzése alapján látható, hogy ezen klaszter tagjai a „leggazdagabbak” a négy klaszter közül (57,6\%). A válaszadók vásárlási attitűdjét jelentősen meghatározzák a független, külső hatóság figyelembevételével történő vásárlások, valamint a csomagoláson látható jelölési információk, továbbá a vásárlás során a beszerzési forrásba (származási helybe) vetett bizalom.

A 2. és 3. klaszter esetében a személyek 52,5\%-a, illetve 45\%-a tartozik az első három (magas, közepesen magas, közepes) szocio-ökonómiai besorolásba.

A 2. klaszterbe tartozó válaszadók elsősorban a beszerzési forrásba vetett bizalom alap- ján döntenek egy adott termék megvásárlásáról.

A 3. klaszter vásárlási attitűdjeit az 1. klaszterhez hasonlóan mind a három „információforrás" meghatározza, de csak közepes mértékben. A 3. klaszter vizsgálata után feltételezhető, hogy további tényezők határozzák meg a vásárlási szokásokat, amely további vizsgálat tárgya lehet a jövőben.

A 4. klaszter a „szegényebb” (39,7\%), mely klaszterben a legmagasabb (33,6\%) értékü az alacsony szocio-ökonómiai csoportba tartozók aránya a másik három klaszterhez viszonyítva.

A 4. klaszter (legszegényebb) vásárlási attitűdjét elsősorban a független, külső hatóság megítélése alapján történő vásárlás határozza meg, a másik két „információforrás” csak másodlagos.

A kérdőív szempontjából figyelembe kell venni, hogy torzító hatást kelthet az, hogy a kérdést az egész családra vonatkoztatták, nem pedig az egyénre. A másik, fontos tényező, hogy személyes megkérdezés során válaszoltak a megkérdezettek, így nagyobb eséllyel találkozhatunk a „pozitív benyomáskeltés” miatt adott torzító válaszokkal is. Többen szeretik jobb színben bemutatni és lefesteni magukat, így ezen lehetőség figyelembevételével is számolnunk kell.

További torzító tényezőként merülhet fel a beválasztási kritériumok bevezetése is. A teljesség igénye érdekében éppen ezen okból került lefuttatásra a teljes, reprezentatív adatbázis $(\mathrm{N}=1$ 038) is, melyről az eredményeknél érintőlegesen olvasni lehet.

\section{5. ÖSSZEFOGLALÁS - SUMMARY}

Jelen kutatásban elemzésre kerültek azon OMNIBUSZ kutatásban található állítások, melyek az élelmiszerekkel kapcsolatos kockázatok csökkentésére irányuló magatartásformák 4 változóját kísérelték meg behatárolni. A vizsgált kérdéskörben felsorolt állítások 4 fókomponense:

1. független, külső hatóság megítélése alapján történő vásárlás,

2. jelölés alapján történő vásárlás (bio-, ökoélelmiszer, gyártó, termelő, címke, nagy termelő, szezonális), 
3. beszerzési forrásba vetett bizalom alapján történő vásárlás,

4. élelmiszer-technológia alapján történő vásárlás.

(Az eredmény a Magyarországon 2013-ban végzett OMNIBUSZ kutatás alapján, a beválasztási kritériumok figyelembe vételének feldolgozásával készült.)

E fókomponensek elemzése után az első 3 fókomponens került bele a modellbe, mivel a statisztikai elemzés alapján nem volt szignifikáns az „élelmiszer-technológia alapján történő vásárlás” klaszterező változó $(\mathrm{F}(2,706)=2,154$, $\mathrm{p}=0,117)$.

Az így kapott eredmények segítségével létrejött modell elsődleges tartalma, hogy a fogyasztók információ szükséglete nagyon magas. A fogyasztó nem azonos, hanem eltérő területeken informálódik az élelmiszer-bevásárlás előtt, után és közben is. Az információforrásra irányuló szükségletei, valamint igényei eltérő módon - például: a címkére, a jelölésre, a termékazonosításra, technológiára, termelőre, gyártóra, egészségtudatosságra, környezetvédelemre, stb. - jelennek meg az állításokban, teret adva erre vonatkozóan a pontosabb differenciálás lehetőségének. A nemek, a korcsoportok és a szocio-ökonómiai vizsgálatok eredményei alapján a 4 fókomponens közötti fő különbséget a szocio-ökonómiai csoport fogyasztóra gyakorolt hatása adta. Az alacsony, a közepesen alacsony és a közepes („szegényebb”) státuszú csoportok hasonló válaszokat jelöltek. Hozzájuk viszonyítva azonban a magas és a közepesen magas („tehetősebb”) szocio-ökonómiai státuszú válaszadók másik, eltérő állításcsoportot preferáltak. A vizsgált minta alapján a szocio-ökonomiai háttér tehát hat az élelmiszer-fogyasztási szokásokra.

A kapott adatbázis vizsgálata során az élelmiszerekkel kapcsolatos kockázatok csökkentését befolyásolható információkra rávilágítottunk, melyek a kapott OMNIBUSZ adatai alapján, a 883 válaszadó tekintetében kiemelt szerepet játszottak. A megállapított magatartásformák tovább bővíthetőek, melyek azonban már egy új kutatás tárgyát képezhetik.

Egy, az NRC PIACKUTATÓ INTÉZET (2014) által készített reprezentatív kutatás $(\mathrm{N}=1$ 200) alapján szintén arra az eredmény- re jutottak, hogy a magyar élelmiszer-vásárlók attitűd értékrendszere a változás korszakába lépett. A magyar fogyasztó élelmiszer-bevásárlásaira korábban a „legolcsóbbat keresem” attitűd volt a jellemző. A 2014-es NRC kutatás során beérkezett válaszok vizsgálati eredményeire támaszkodva már hátrébb sorolódott az árérzékeny fogyasztó, mivel megjelent a tudatos fogyasztók azon rétege, akiket már a magasabb minőség és a megfelelő ár-érték arány jobban befolyásol az élelmiszer-bevásárlás során. A két kutatási eredmény elméleti síkon egymást támogatja a magyar élelmiszer-fogyasztók magatartásformáinak definiálása, illetve az információk iránti egyre növekvő szükségleteik megfelelő kielégítésében.

Ezúton is szeretném megköszönni az adatbázis nyújtotta lehetőséget Prof. Dr. Lehota Józsefnek, aki a Szent István Egyetem képviseletében lehetőséget adott az adatbázis hozzáféréséhez, valamint konzulensemnek, Dr. Komáromi Nándornak támogató munkájáért.

\section{IRODALOMJEGYZÉK - REFERENCES}

Csite A. - Kovách I. - Kristóf L.: Fogyasztói csoportok az ezredforduló Magyarországán. In: Társadalmi metszetek. Érdekek és hatalmi viszonyok, individualizáció és egyenlőtlenség a mai Magyarországon. (Szerk.: Kovách I.): Budapest, Napvilág Kiadó, 2006. 253-291.

Dowler, E.: Social Exclusion, Food Poverty and Access to Healthy Food: Key Issues and Policy Interventions at Local and National Levels. One-day Conference on Local Food and Health. Foundation for Local Food Initiatives, Birmingham, June, 2011.

Gossard, M. H. - York, R.: Social Structural Influences on Meat Consumption. Human Ecology Review. 2003. 10 (1) 1-9.

Hayn, D. - Empacher, C. - Halbes, S.: Trend und Entwicklung von Ernährung im Alltag. Ergebnisse einer Literaturrecherche. Thesis: Institut für sozialökologische Forschunge, Frankfurt am Main, 2005. 
Hofmeister-Tóth Á. - Kelemen K. - Piskóti M.: Környezettudatos fogyasztói magatartásminták a magyar háztartásokban. Magyar Marketing Szövetség 16. Országos Konferenciája, „Uj Marketing Világrend”. 2010. augusztus 26-27. Budapest

Horváth Á.: Fogyasztói magatartás. Szent István Egyetemi Kiadó, Gödöllő, 2010.

Hulshof, K. F. - Löwik, M. R. - Kok, F. J. - Wedel, M. - Brants, H. A. Hermus, R. J. - Hoor, F.: Diet and Other Life-style Factors in High and Low Socio-economic Groups. Dutch Nutrition Surveillance System. European Journal of Clinical Nutrition. 1991. 45 (9) 441-450.

Irala-Estevez, D. J. - Groth, M. Johansson, L. - Oltersdorf, U. Prattala, R. - Martinez-González M. A.: Systematic Review of Socio-economic Differences in Food Habits in Europe: Consumption of Fruits and Vegetables. European Journal of Clinical Nutrition. 2000. 54 (9) 706-714.

Johansson, L. - Thelle, D. S. - Solvoll, K. - Bjorneboe, G. E. - Drevon, C. A.: Healthy Dietary Habits in Relation to Social Determinants and Lifestyle Factors. British Journal of Nutrition. 1999. 81 (3) 211-220.

Kocsis T.: A fogyasztói szemléletváltás esélye a gazdaságilag fejlett országokban. In: Környezeti nézópontok - Tanulmányok a Környezetgazdaságtani és Technológiai Tanszék 15 éves fennállása alkalmából. Budapesti Corvinus Egyetem Környezettudományi Intézet Környezetgazdaságtani és Technológiai Tanszék, Budapest, 2006. 15-31.

Kotler, P. - Keller, K. L.: Marketingmenedzsment. Akadémia Kiadó, Budapest, 2006.

Lehota J.: Marketingkutatás az agrárgazdaságban. Mezőgazda Kiadó, Budapest, 2001.
Lehota J.: Az élelmiszerfogyasztói magatartás hazai és nemzetközi trendjei. Élelmiszer, Táplálkozás és Marketing. 2004. 1 (1-2) 7-14.

NRC Piackutató Intézet: Élelmiszer kutatás. 2014. URL: http://nrc.hu/ fmcg-szektor/elelmiszer-kutatasarerzekenyseg-a-vasarlasnal/ (Letöltés dátuma: 2016. aug. 20.)

Payer, H. - Burger, P. - Lorek, S.: Food Consumption in Austria: Driving Forces and Environmental Impacts. National case study for the OECD Programme on Sustainable Consumption. Vienna, Federal Ministry of Agriculure, Forestry, Environment and Water Management, 2000.

Roos, E. - Prattala, R. - Lahelma, E. Kleemola, P. - Pietinen, P.: Modern and Healthy: Socioeconomic Differences in the Quality of Diet. European Journal of Clinical Nutrition. 1996. 50 753-760.

Roos G. - Johansson, L. - Kasmel, A. - Klumbiene, J. - Prättälä, R.: Disparities in Vegetable and Fruit Consumption: European Cases from the North to the South. Public Health Nutrition. 2001.4 (1) 35-43.

Smith, A. M. - Baghurst, K. I.: Public Health Implications of Dietary Differences between Social Status and Occupational Category Groups. Community Health. 1992. 46 (4) 409-416.

Törőcsik, M.: Fogyasztói magatartás Insight, trendek, vásárlók. Akadémia Kiadó, Budapest, 2011.

Szarka K. - Lehota J. - Langer K.: Fears Regarding Suistainability of the 50+ Generation. Journal of Central European Green Innovation. 2014.2 (4) 129-151.

Vető-Mózner Zs.: Az élelmiszerfogyasztás szerkezete és környezeti hatása Magyarországon. Marketing és Menedzsment. 2014. 48 (3) 57-70. 


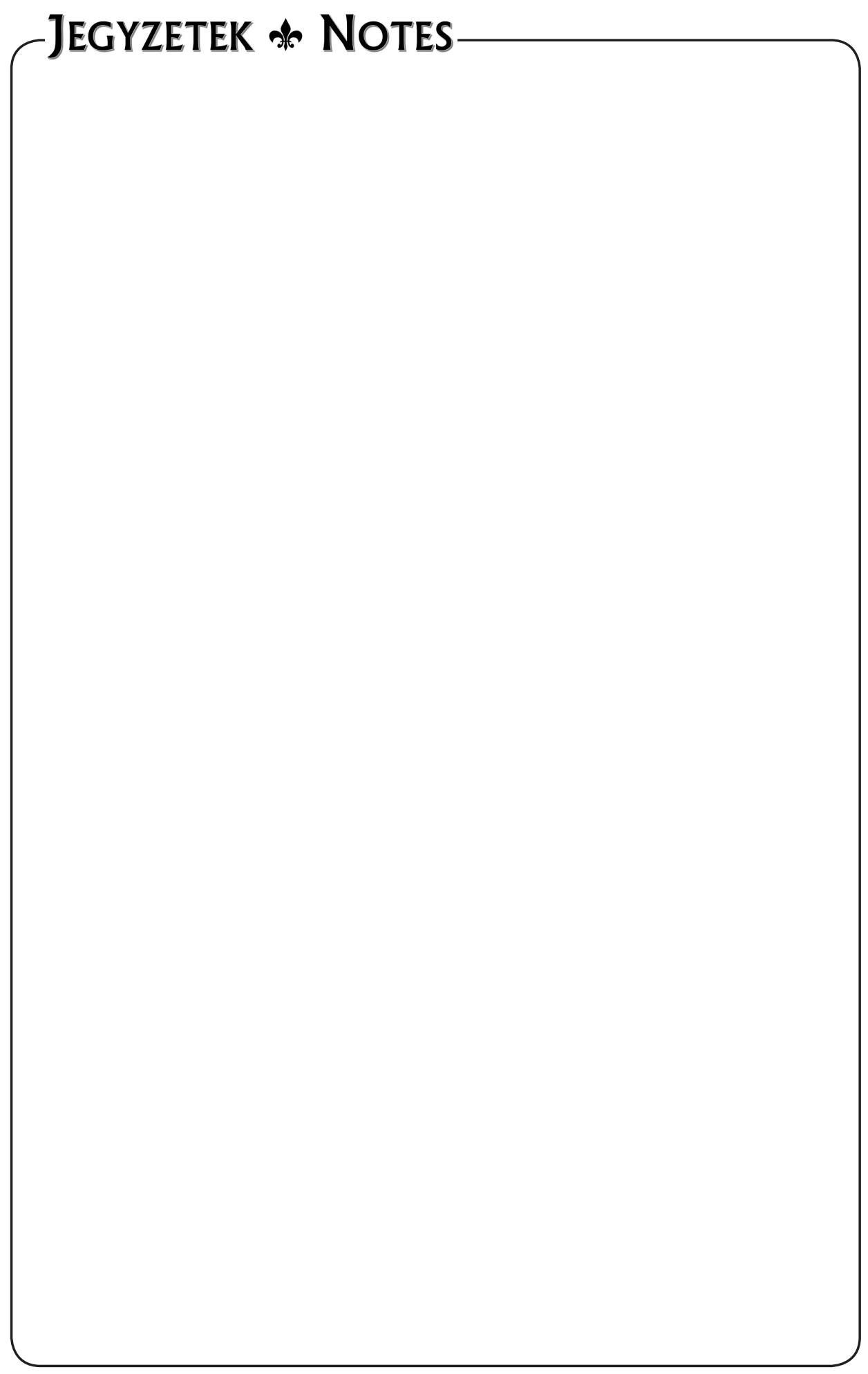

